\title{
The Probability of the Resurrection of Jesus
}

\author{
Richard Swinburne \\ [Swinburne, Richard, 2013, "The Probability of the Resurrection of Jesus", Philo- \\ sophia Christi 15, 239-252.]
}

In this paper I shall seek to summarize an argument contained in my recent book Was Jesus God? (as well as more fully in my book The Resurrection of God Incarnate) ${ }^{1}$ arguing for the high probability that Jesus rose bodily from the dead on the first Easter Day.

In assessing any historical hypothesis we have to take into account three kinds of evidence. The first kind is the most obvious kind - the testimony of witnesses about and the physical data caused by what happened at the time and place in question. If it is suggested that John robbed a certain safe, then our obvious historical evidence is what witnesses said (about who was near the safe at the time in question, and where John was at that time), and physical data such as fingerprints on the safe, money found in John's garage etc. I shall call such evidence the posterior historical evidence. In so far as the hypothesis is a simple one, and the posterior historical evidence is such as you would expect to find if the hypothesis at stake is true but not otherwise, that is evidence that the hypothesis is true. For example, if John robbed the safe, you would expect to find his fingerprints on it but would not expect to find them if he didn't; and in the absence of evidence for a hypothesis of the unreliability of witnesses, if John robbed the safe you would expect that any people who saw John at the time or were near the safe at the time, to say that they saw John there, but would not expect them to say this if they didn't.

I stress here, as elsewhere else in this paper and in everything else I have written, the crucial importance of its simplicity in assessing the truth of a theory. There are always an infinite number of possible theories in science, history, or any other sphere of inquiry, which are such that if they were true, you would expect to find the evidence that you do. John's fingerprints being on the safe, and the testimony of George to John's presence at the scene of the theft at the time of its occurrence, and John having a lot of money hidden in his garage, could easily be explained by Harry having planted John's fingerprints there for a joke, George telling a lie because he disliked John, and Jim having put the proceeds of a quite different robbery 
into John's garage. But, in the absence of further evidence, the theory that John did the crime is that most likely to be true (that is, most probably true), because it is the simplest in postulating that one person (John) doing one action (robbing the safe) caused in different ways the three pieces of evidence.

As well as the posterior historical evidence, we need to take into account general background evidence of how likely the hypothesis is to be true, independently of the detailed historical evidence. In my humble example this evidence will be evidence of John's past behaviour, and the past behaviour of other suspects which might, for example, support strongly (as its simplest explanation) a theory that John is not the sort of person to rob a safe, whereas George is just that sort of person. In that case, even if the posterior historical evidence is exactly what we would expect if John robbed the safe, but not quite what we could expect if George had robbed the safe, nevertheless we may rightly conclude that George is the most probable culprit.

In this example, the background evidence was fairly narrow John or George's past behaviour. But the joint influence of background evidence and posterior historical evidence operates where the background evidence is far more general. Suppose an astronomer observes through his telescope a certain pattern of bright dots which is exactly what you would find if these dots were the debris of a supernova explosion. It is right so to interpret them if your theory of physics, as best supported by all the other evidence available to the physicist - that is, the general background evidence allows that supernovae can explode. But if your theory of physics says that supernovae cannot explode, then the hypothesis that one did on this occasion will need an enormous amount of detailed historical evidence (itself vastly improbable on any hypothesis of equal simplicity other than the hypothesis that it was caused by a supernova explosion), before we can regard that as probable - and if we do so regard it, we will have to regard the whole theory of physics which rules it out, as itself improbable, given our new detailed historical evidence.

The general background evidence may indicate not simply that the postulated hypothesis is or is not likely to be true, but that it is likely to be true only under certain conditions - for example, that John is likely to rob safes when and only when financially broke, or that supernovae are likely to explode when, and only when, they reach a certain age. In that case another kind of historical evidence will enter the equation, evidence showing that those conducive conditions (what I shall call the prior requirements) were or were not present. That again will be strong in so far as it is such as you would expect to find if those conditions were present, and not otherwise 
(and in so far as the supposition of these conditions is a simple one). I shall call such evidence the prior historical evidence.

When we are dealing with a hypothesis $\mathrm{H}$ which would be not too improbable on one world-view $\mathrm{T}$ but would be immensely improbable on a rival world-view, the general background evidence will be all the evidence which is relevant to the probability of the different world views; and to the extent to which it supports most strongly the world-view $\mathrm{T}$ which makes $\mathrm{H}$ not too improbable, we need less by way of detailed historical evidence in order for the claim that $\mathrm{H}$ is true, to be probable overall. The hypothesis that Jesus rose from the dead is of just this kind. For if there is no God, the ultimate determinant of what happens in the world is laws of nature, and for someone dead for 36 hours to come to life again is (with immense probability) a clear violation of those laws and so impossible. This is for the reason which Hume gave - that all the evidence that some regularity operated on very many known past occasions is evidence that it is a law of nature and so operated on this occasion too, and so that Jesus did not rise. But if there is a God of the traditional kind, laws of nature only operate because he makes them operate, and he has the power to set them aside for a moment or forever. Hence, if Jesus rose from the dead, God raised him up. So I shall treat the hypothesis that Jesus rose as equivalent to God raised Jesus. But if there is a God with the power to raise Jesus, he will only do so in so far as he has reason to do so; and, if he doesn't this Resurrection is not to be expected.

So to determine whether Jesus rose from the dead, it is not enough to investigate whether what I have called the posterior historical evidence (what St. Paul and the Gospel writers wrote about what witnesses said that they saw from three to forty days after the crucifixion) is the kind of evidence to be expected if Jesus rose, but not otherwise. One must also investigate whether general background evidence supports the world-view that there is a God of a kind able and likely to intervene in human history in this kind of way in this kind of situation, or whether there is no such God. And we must also investigate the prior historical evidence - that is, whether the nature and circumstances of the life of Jesus were such that if there is a God, he would be likely to raise this person from the dead. In so far as our general background and prior historical evidence supports the view that there is a God who would be likely to raise Jesus from the dead, we shall need a lot less by way of detailed historical evidence in order for it to be overall probable on our total evidence that Jesus rose from the dead. Conversely, in so far as our prior evidence (background or historical) supports a rival world-view that there is no God (of the traditional kind) or that if there is such a God he has no reason to intervene in human history in this kind of way, or that even if God does have such reason, Jesus was not the 
sort of person whom he would have brought to life again, we would need an immense amount of posterior historical evidence in order for our total evidence to make it probable that Jesus rose. It is the total failure of almost all New Testament scholarship to take this crucially relevant kind of evidence into account, which may make its conclusions about the probability of the Resurrection and other New Testament events seriously erroneous.

I have argued at considerable length over many years ${ }^{2}$ in favour of the view that the existence of a universe, its almost total conformity to natural laws, those laws being such as to lead to the evolution of human beings, those human beings having souls (a continuing mental life whose continuity is separate from the continuity of their physical life), the occurrence of various events in history, and millions of humans having experiences which seem to them to be of God, is evidence which (despite the occurrence of evil) makes probable the existence of God. Now there is no time to reargue that here. So let's suppose for the moment, in order to proceed further merely that on this kind of evidence (the evidence of 'natural theology' as it is called) it is as likely as not that there is a God. If there is a God, clearly he could, if he so chose, raise Jesus from the dead. Hence, to the extent to which, in virtue of his goodness, he has reason to do so, it is probable that he will. God very seldom raises the dead (in their original bodies while others on Earth continue their normal life). Jesus would therefore need to be a very special sort of person for God to have reason to raise him. There might be various reasons why God would choose to raise Jesus, but I shall consider here only the reasons which God would have if Jesus was God Incarnate (that is, God who had acquired a human nature) - because, as we shall see later, given the evidence of the kind of life Jesus lived, he would only have raised him if he was God Incarnate. That is, I shall argue that in virtue of God's goodness, he had reason to become incarnate and live a certain sort of life, and that if he did so, God has reason to raise him from the dead.

Theologians have always claimed that a major reason why God would choose to become incarnate was to make atonement for human sins. All humans have wronged God seriously (that is, sinned seriously), because they have failed to show gratitude and obedience to their creator who made them from nothing and keeps them in being from moment to moment. When we do wrong to someone, we must repent and apologize, but we must also try to provide reparation for the wrong we have done. And it is good that someone wronged seriously (in this case God) should require the wrongdoer to make some serious attempt at reparation before forgiving him - for that forces the wrongdoer to take his wrongdoing seriously. But alas we who owe much to God already are in no position to provide 
reparation for our past sins. Yet while the wrongdoer must himself repent and apologize, someone else can provide him with the reparation for him to offer back to the person wronged. God incarnate could provide a perfect human life for us to offer back to God as our reparation for the life we ought to have led. One who lives a perfect life in typical human circumstances may well be killed for it; and such a death would complete a perfect life. We can then say 'please accept this life and death instead of the life we ought to have led'. This reparation is then a sacrifice offered to God, and a Resurrection would constitute God's demonstration to us that the sacrifice had been accepted and that forgiveness is available. ${ }^{3}$ For the resurrection of someone dead for thirty six hours would, as I have noted, be a violation of laws of nature, and this could only be done by him who keeps the laws of nature operative - God. The second reason why God would choose to become incarnate is a reason which would operate even if humans had not sinned. God made humans subject to pain and suffering of various kinds caused by natural processes. God, being perfectly good, would only have permitted this subjection if it served some greater goods. Theodicy seeks to explain what are the relevant greater goods ${ }^{4}$ - for example, the great good of humans having the significant free choice of whether to cope bravely with their own suffering and show compassion to others who suffer. We humans sometimes rightly subject our own children to suffering for the sake of some greater good (to themselves or others) - for instance, make them eat a plain diet or take some special exercise for the sake of their health, or make them attend a 'difficult' neighbourhood school for the sake of good community relations. Under these circumstances we judge it a good thing to manifest solidarity with our children by putting ourselves in somewhat the same situation - share their diet or their exercise, or become involved in the parent/teacher organization of the neighbourhood school. Indeed, if we subject our children to serious suffering for the sake of a greater good to others, there comes a point at which it is not merely good but obligatory to identify with the sufferer and show him that we have done so. A perfectly good God would judge it a good thing to share the pain and suffering to which he subjects us for the sake of greater goods -by becoming incarnate. Living a holy life protesting against injustice under difficult conditions, is liable to lead to execution. God needs to have told or shown us that he is God Incarnate. In that case his Resurrection would constitute God's signature on that teaching, and so show us that God has identified with our suffering.

And finally, we need better information about how to lead good lives in future, and encouragement and help to do so. Humans can, and to some extent in the centuries B.C. did, find out for themselves what is right and wrong. But although the outlines may be 
discoverable, the details are not easy to discover - are abortion and euthanasia always wrong, or only wrong under certain conditions; are homosexual relationships sometimes permissible, or never, etc. and in all these matters, humans are prone not to face the deliverances of their consciences. They need information. True, this could be provided through a revelation to some prophet without any need for incarnation. But moral information needs to be filled out by moral example - we need to be shown what a perfect life consists in, and that God has no right to tell anyone else to do for him. It would be good for this information to include encouraging information, e.g. that God will take us to Heaven if we trust him and fulfil his commandments. And it would be good if God gave us some extra help in leading the moral life - a community of encouragement, for example a church. Again, God raising someone killed for certain teaching and living a certain life constitutes his signature on that teaching.

We have now three reasons of why a good God might choose to become incarnate in such a way as to suffer and probably die, and how he would need to show us that it was he who had done this which would be achieved by a super-miracle such as a Resurrection. In my view, while it is quite probable that in virtue of his goodness God might choose to become incarnate for the first and third reasons, he has no obligation to do so and there are other ways (perhaps less satisfactory ways) of dealing with the problems to which his incarnation for these reasons would provide a solution. But in my view, given the extent of human suffering, our creator has an obligation to share it with us and so it is necessary that he will become incarnate for the second reason.

So, if God did become incarnate in some human (let us call him a prophet) for the second reason and one or both of the other reasons, he would need to live a certain sort of life. To identify with our suffering and to provide an example for us God Incarnate needs to live a good life in difficult circumstances, and a good but hard life ending in a judicial execution would certainly be that. To show us that he is God who has done this, he needs to show us that he believes himself to be God. To enable us to use his life and death as atonement for our sins, he needs to tell us that he is leading his life for this purpose. In order to make it plausible that he is preaching a revelation, he needs to give us good and deep moral teaching on how to live. And to make all this available to generations and cultures other than that in which he lived, he needs to found a church to teach humans what he has done and to apply to them his atoning life. So we have prior reason for expecting a resurrection, not of any human, but of a human about whose life our evidence is what we would expect if he had led a life of the above kind. The stronger the background evidence that there is a God whose goodness would lead 
him to become incarnate for the stated reasons, and the stronger the prior historical evidence that Jesus led the sort of life described above, the stronger reason we have for supposing that God would put his signature it by a super-miracle such as his Resurrection.

My assessment of the balance of New Testament scholarship is that it holds that the evidence is such as we would expect if Jesus led a good and holy life, gave us good and deep moral teaching, and founded a church, which did teach that he was God Incarnate who atoned for our sins. It is, I suggest, impossible to understand his forming a community of twelve leaders except as forming a new Israel, whether in the end he intended it to become independent from or merge back into the old Israel. New Testament scholarship is, however, divided about whether the evidence is such as one would expect if and only if Jesus proclaimed that his life and death was an atonement for sin; and on the whole it claims that the evidence is not such as would be expected if Jesus believed himself divine.

So let us now turn to these more disputed issues about life of Jesus. I suggest that on balance the evidence shows that Jesus did believe that he was divine. If God was to become incarnate for the purposes I've discussed, he needed to take a human nature (a human way of thinking and acting) and a human body in addition to his divine nature (in the way that the council of Chalcedon defined in 451 A.D.) This is a pretty complicated concept to get hold of. If Jesus had announced during his earthly ministry 'I am God', this would have been understood as a claim to be a pagan god, a powerful and lustful being who had temporarily occupied a human body (not the all-good source of all being). The well known Jewish scholar Geza Vermes writes that it is no exaggeration to contend that the identification of a contemporary historical figure with God would have been inconceivable to a first-century AD Palestinian Jew. ${ }^{5}$

So the failure of Jesus to say 'I am God' during his lifetime is not evidence that he did not believe himself to be God. This is a message which Jesus could begin to proclaim openly only after his crucifixion had made very plainly the reality of his humanity and so the kind of god he would have to have been; and after his Resurrection had provided evidence of his unique status. And there is evidence that he did begin to proclaim this more openly then. St Matthew's Gospel ends with Jesus commanding the Eleven to baptize 'in the name of the Father, and of the Son, and of the Holy Spirit'. ${ }^{6}$ This saying puts 'the Son' (Jesus) on a level with God the Father. Critics, rightly ever on the watch for later interpolations, have, of course, cast grave doubt on the authenticity of this verse; but the manuscript tradition is unanimous and thus early. Then St John records the explicit confession by the formerly doubting, now convinced, Thomas, of Jesus as 'My Lord and my God'7, a confession which Jesus did not 
reject. On two post-Resurrection occasions St Matthew's Gospel ${ }^{8}$ records that disciples 'worshipped' Jesus; and many ancient manuscripts record a similar 'worship' by the Eleven at the end of St Luke's Gospel ${ }^{9}$. The New Testament writers regarded 'worship' as appropriate only to divinity. It is so regarded in several distinct New Testament passages. In Matthew 4:10 (parallelled in Luke 4:8) Jesus quotes Deuteronomy 6:13, 'Worship the Lord your God and serve only him', in response to the Devil's invitation to worship him (the Devil). In Acts 10:26 Peter stops Cornelius worshipping him with the words 'Stand up: I am only a mortal'. And twice in Revelation the angel commands 'John' not to worship him with the words 'You must not do that! I am a fellow-servant with you ... Worship God'10. Jesus on the other hand never rejected worship; and St. Matthew does record also pre-Resurrection occurrences of worship of Jesus. This evidence is such as we would expect if Jesus was God Incarnate, even if liberal critics claim that it can be accounted by the Gospel writers reading such claims back into history in the light of the Church's later beliefs.

As Jesus could only confess his divinity after his Resurrection, and as even then it might not be easily comprehensible by his followers, he would need also to leave plenty of clues in his life, reflection on which could give his followers after his life was finished the understanding of who he was. And I think that he did that; and I shall consider one important example of that, a piece of evidence which critics are much less willing to regard as a later construction. This is the claim that the Jews regarded Jesus as 'blasphemous'. The synopists (that is, Matthew, Mark and Luke) explicitly connect a comment by the scribes who heard Jesus's words of forgiveness to the paralytic man that 'It is blasphemy! Who can forgive sins, but God alone?'11 Mark and Matthew report that the charge against Jesus before the Sanhedrin was 'blasphemy'12. Now clearly Jesus did not curse God, and so his blasphemy must involve his claiming divine prerogatives. And where or not you think St John actually records a Jewish comment, he clearly understood their accusation of blasphemy in this way. In John 10 the Jews attempt to stone Jesus, saying 'It is not for a good work that we are going to stone you, but for blasphemy, because you, though only a human being, are making yourself God. ${ }^{13}$

Now, according to the synoptic Gospels, two issues were raised at the trial of Jesus before Caiaphas, both relevant to the accusation of blasphemy. Jesus was asked whether he was the Messiah. Claiming to be the Messiah would in itself hardly be arrogating divine prerogatives. But Jesus's quoted response developing the theme of his being Messiah by quoting Daniel 7, 'You will see the Son of Man, seated at the right hand of power', and 'coming with the clouds of Heaven' was claiming a very high kind of Messiahship; and 
it was to that comment that, according to Mark, Caiaphas responded with 'You have heard his blasphemy.' ${ }^{14}$ Now again it is not obvious that even this remark of Jesus is claiming divinity; and critics have claimed that even Jesus's explicit confession of Messiahship at this time was an invention of St Mark.

But the other issue raised at the trial is more interesting, because Mark claims that the witness testimony was false and so it is hardly his invention. Mark (and Matthew) record the charge that Jesus would or could destroy the (sanctuary of the) Temple and build it again in three days. To quote very liberal biblical scholar E.P. Sanders: 'It is hard to imagine a purely fictional origin for the accusation that [Jesus] threatened to destroy the Temple.' Mark described this accusation as 'false' ${ }^{16}$. But probably Mark, and certainly Matthew, who has the same passage, believed that the Temple was destroyed (for they wrote after the time of its destruction in 70 A.D.); and, like the other synoptists, Mark reports elsewhere a further prediction by Jesus of its destruction ${ }^{17}$. So the falsity of the accusation (in their view) must lie in one of two things: Jesus did not threaten himself to destroy the Temple, but merely predicted that it would be destroyed; and/or he did not promise to build another in three days. But since both Mark and Matthew believed that he did build in three days something else which had been destroyed 'not made with hands' that is, himself which, when the Temple was destroyed, they came to regard as a replacement for it; the falsity in their view is more likely to consist in the fact that Jesus did not threaten to destroy the Temple but merely predicted that it would be destroyed. Luke describes Jesus as warning, at the time of the Passion, the 'daughters of Jerusalem' of a time of disaster ${ }^{18}$, and Mark, in the chapter preceding the Passion narrative, records Jesus as predicting the destruction of the Temple ${ }^{19}$. So Jesus indeed predicted the destruction of the Temple; but by another rather than himself. John too quotes Jesus as saying 'destroy this temple, and in three days I will raise it up. ${ }^{20}$ To replace the divinely instituted worship of the Temple with another kind of worship was clearly God's privilege; and Jesus is not reported as saying that God had commissioned him to do this - he is reported as saying that he would do it himself. And that is a claim to divinity.

And it leads me on quickly to the issue of whether Jesus claimed that his life was an atonement. The above quotation which, as we have seen, can hardly be regarded as an invention, constitutes Jesus's claim that he will provide a substitute for Temple sacrifices, which were made in order to achieve atonement for sin. And then there is the Last Supper, a solemn meal at Passover time, in which Jesus gave to his disciples bread and wine with the words 'This is my body', and 'This is my blood'. Body and blood are the elements of sacrifice. Jesus is telling his disciples that his life is a sacrifice; and 
so that he is himself the substitute for the Temple. All the New Testament accounts for the Last Supper regard it as a 'new' covenant, and they knew that Jeremiah has prophesied a 'new covenant' which he connected with 'the forgiveness of sins.' ${ }^{21}$ And then of course there is the widespread unanimous New Testament consensus, so widespread that it would be unreasonable to suppose that it had no origin in the teaching of Jesus, that Jesus died for our sins.

So I suggest that in all respects the historical evidence is such as you would expect if Jesus satisfied the prior requirements for being God Incarnate. In the light of all our reasons for supposing that there is a God who would become incarnate and live a certain sort of life, we have good reason in advance for expecting an event such as the Resurrection to culminate the life of Jesus who did live of the requisite kind. So we don't need too much detailed posterior historical evidence to suppose that the resurrection actually happened. But there is significant posterior evidence to be expected if Jesus rose (and not otherwise); and so finally let us look at it. If Jesus rose bodily from the dead on the first Easter Day, we would expect two sorts of witness - evidence: witnesses who talked with a person whom they took to be Jesus, and witness who saw the empty tomb.

On the first, Matthew, Luke, John, I Corinthians provide lists of witnesses who, they claim, talked with Jesus. Acts twice records that Jesus appeared to his disciples for many days. The earliest text of Mark's Gospel is generally thought to have ended at 16.8 with the story of the women finding the empty tomb, and before anyone met the risen Jesus. 16.9-16.20 is a later addition summarising what is recorded in other Gospels, primarily Luke. But the earlier parts of Mark contain three separate predictions of the Resurrection, and Mark 16.7 reports a young man in white predicting an appearance of Jesus to the disciples in Galilee. So Mark certainly believed that Jesus appeared to his disciples after his Resurrection, and to my mind the most probable explanation of why the earliest text we have of the Gospel ended at 16.8 is that there is a lost ending. The last part of the manuscript was lost, and so what we have in today's Bible was added by some later scribe to summarize some main appearances of Jesus which the other Gospels recorded.

So there are a lot of reports of individuals and above all of groups of individuals seemingly talking to the risen Jesus; and while individuals might imagine things, it would be massively improbable to have joint illusions of Jesus saying the same thing in the course of conversations. You could suppose that the whole Christian community had a programme of deliberate deceit, when giving these reports. But not even the average agnostic or atheist would suggest 
that - in view of what we know about the characters of those involved.

Our main sources do however give somewhat different lists of who saw Jesus where and when; and this is often thought to be a major discrepancy casting doubt on the whole story. There is however a reason for some of the discrepancy, that the writers had different purposes in producing their lists. Priority must go to the list in I Corinthians. I Corinthians is the earliest of these sources, written by Paul in about 55 A.D. (This would be agreed by all serious scholars). The text ${ }^{22}$ has the form of a credal statement, a church recognized list of 'witnesses'. Paul repeats it to the Corinthians as what he had told them previously, and what he himself had 'received' (apart, that is, presumably, from Christ's appearance to himself). This was that Jesus appeared first to Peter, then to the Twelve, then to the 'above five hundred brothers and sisters at one time, most of whom are still alive, though some have died', then to James, and then to all the apostles, and finally to Paul himself 'as to one untimely born'. The implication of the latter phrase is that the appearance to Paul was much later than the other appearances. The 'then's' imply a temporal sequence of appearances. Paul tells us in Galatians ${ }^{23}$ that, soon after his conversion, he spent fifteen days with Peter in Jerusalem, where he also met 'James, the Lord's brother', and where he must have heard what Peter and James had to say about the basis of this central Christian message; what he records in I Corinthians must have been sensitive to those conversations.

The Gospels however all include appearances earlier than the first appearance listed by Paul - Matthew and John include an appearance to Mary Magdalen, and Luke includes an appearance to Cleopas and another disciple. So why don't these occur in the official list? There is an obvious answer. The official list contains people whom the Jews would take seriously. They would not take women witnesses seriously. (The contemporary Jewish writer Josephus states that Moses prohibited recognizing women as witnesses. Cleopas was not a senior church leader , and his companion may well have been his wife apparently mentioned in John 19:25 as being present at the Crucifixion.)The Gospels being written later (when Jewish attitudes had hardened) and being more interested in the historical sequence put things differently.

And then the empty tomb. All four Gospels begin their accounts of the Resurrection with the visit by the women to the tomb which they found empty. It used to be said that as I Corinthians, the earliest source, does not mention the empty tomb, this visit and the tomb being empty was a later invention of the Gospel writers. But even the Jews acknowledged that the tomb was empty. For Matthew 28.15 records that they claimed that the disciples had stolen the body, 
which they would not have claimed if they did not believe that the tomb was empty. Why Paul didn't mention it is because he didn't need to. Resurrection for a Jew meant bodily resurrection.

And there is one crucial largely unrecognized piece of evidence in favour of the women having visited the tomb on the first Easter Day and having found it empty. Christian communities spread out from Jerusalem very quickly - within three or four years of events of the Passion. They took with them their customs, including the custom of celebrating a eucharist; and all the evidence we have suggests that there was a universal custom of celebrating the eucharist on a Sunday, the first day of the week. This must have antedated the scattering; otherwise we would have heard of disputes about when to celebrate, and some instructions being given from on high (analogous to the way in which disputes about circumcision and eating sacrificial meat were purportedly resolved by the 'Council of Jerusalem' described in Acts 15). All references in early Christian literature to when the eucharist was celebrated refer to a weekly Sunday celebration. And the one apparent explicit reference in the New Testament to a particular post-Ascension celebration of the Eucharist also describes a Sunday celebration. Acts 20:7 records a 'breaking of bread' on a 'first day of the week'. 'To break bread' was the expression used by St Paul (I Cor.) for what Jesus did at the Last Supper, and was always used later as a description of the common Christian meal which included the eucharist. This verse is one of the 'we' passages in Acts. These are the passages in which Paul's journeys are described in terms of what 'we' did and what happened to 'us'; and so probably reflect the participation of the author of Acts (Luke) or his immediate source. I Corinthians 16.2 implies that Christian communities met together on Sundays; and Rev 1.10 calls Sunday 'the Lord's day'.

There are other days on which it might have been more natural for Christians to celebrate the eucharist (e.g. on the day of the original Last Supper - probably a Thursday and certainly not a Sunday - or annually rather than weekly). No such customs are known. There is no plausible origin of the sacredness of Sunday from outside Christianity. There is only one simple explanation of this universal custom, which, I argued, must derive at the latest from the first two or three post-Resurrection years. The eucharist was celebrated on a Sunday (and Sunday had theological significance) from the first years of Christianity because Christians believed that the central Christian event of the Resurrection occurred on a Sunday. Yet such early practice would have included that the Eleven themselves, and so could only go with a belief of theirs that Christians had seen either the empty tomb or the risen Jesus on the first Easter Sunday. This shows that the visit to the tomb on Easter Sunday was not a late invention read back into history to make sense 
of the appearances but a separately authenticated incident.

I conclude that there is one person in human history who satisfied quite well the prior and posterior requirements for being God Incarnate (that is for living the kind of life which we would expect a God, if there is a God, to live on earth); and that is Jesus. By the prior requirements, to repeat I mean living a good and holy life, giving us good deep moral teaching, showing us that he believed himself to be God Incarnate and that he was making atonement for our sins and founding a Church which taught the latter things. By the posterior requirements I mean his life being culminated by a super-miracle, such as a Resurrection from the dead. And there is no other plausible candidate in human history for satisfying either of these sets of requirements. Other founders of great religions did, of course, live good lives, give deep moral teaching and founded churches - the Buddha, for example. But manifestly the Buddha did not teach his own divinity, nor did Mohammad. And manifestly neither of them taught that their lives atoned for our sins. There have been many modern Messiahs who claimed to be God, but they have not satisfied the other requirements - in particular their lives have not been holy. And no great religion other than Christianity has made a claim to be founded on a super-miracle for which there is in any way the kind of detailed testimony that there is for the foundation miracle of Christianity (inadequate though that might seem to some). Yet the non-existence of any other plausible candidate for satisfying either the prior or the posterior requirements shows that the coincidence of the prior and posterior evidence (even if weak) in one candidate is an extremely unlikely event in the normal course of things - i.e unless God brought it about. But if God did not become incarnate for the stated reasons in Jesus but became incarnate in some other prophet or plans to do so in future, it would be deceptive of him to bring about the existence of the amount and kind of prior evidence of his incarnation in Jesus together with the amount and kind of posterior historical evidence that there is of his Resurrection. It would be like leaving someone's fingerprints at the murder scene when they had not committed the murder. In virtue of his perfect goodness God would not do that sort of thing. If God planned the coincidence in Jesus of the two kinds of evidence, then Jesus was God Incarnate; and it is very improbable that there would be this coincidence unless God planned it.

So if there is a modest amount of evidence of natural theology that there is a God of the traditional kind who might with modest probability be expected to become incarnate for the stated reasons and to have his life culminated by a super miracle such as the Resurrection, and there is only one plausible candidate (Jesus) who satisfied at all well the prior requirements for such an incarnation, you don't need too much posterior historical evidence to make it 
probable that Jesus rose. For it would be most improbable that there would be this combination of prior and posterior evidence unless God arranged it, and it would be deceptive of him to arrange it unless Jesus was indeed God Incarnate. So even if it is only as probable at not that there is a God (that is, a probability of $1 / 2$ ), and a probability of $1 / 2$ that such a God would become incarnate; and even if the historical evidence were only such as it is not very probable that you would find if Jesus was God Incarnate who rose from the dead - let's call it a probability of $1 / 10$, then on balance it is still overall probable that Jesus was God Incarnate and that he rose from the dead because it is so improbable that you would have that evidence if he was not. If we suppose that the probability that we would have this combination of prior and posterior evidence if Jesus was not God Incarnate is $1 / 1000$, then it can be shown ${ }^{24}$ that the total evidence gives a probability of ${ }^{97} / 100$ that Jesus was God Incarnate who rose from the dead. To take an analogy - if the background evidence gives a significant probability, say $1 / 4$, that John would commit a certain crime; and so $3 / 4$ that he wouldn't; and the clues are on balance not such as it is probable you would find if he did commit the crime (although there is a lesser probability that they might still occur if he committed the crime), but are such that it is very improbable indeed that you would find them if he did not commit the crime, then they make it probable that he committed the crime ${ }^{24}$.

I conclude that unless my assessment of how probable the evidence of natural theology makes the existence of God is very badly mistaken, it is very probable that Jesus was God Incarnate and that he rose from the dead.

\section{NOTES}

1. The Resurrection of God Incarnate, Oxford University Press, 2003; and Was Jesus God?, Oxford University Press, 2008.

2. See my The Existence of God, second edition, Oxford University Press, 2004; and the shorter version Is there a God?, Oxford University Press, 1996.

3. For a far fuller account of how the life and death of God Incarnate would make available atonement for human sins, see my Responsibility and Atonement, Clarendon Press, 1989, especially chs 5, 9 \& 10.

4. For my full theodicy, see my Providence and the Problem of Evil, Clarendon Press, 1998.

5. Geza Vermes, Jesus the Jew, SCM Press, 1994, p. 186.

6. Matthew 28:19

7. John 20:28

8. Matthew 28:9 and 28:17.

9. Luke 24:52 
10. Revelation 19:10 and 22:9

11. Mark 2:7

12. Mark 14:64

13. John 10:33

14. Mark 14:64

15. E.P. Sanders, Jesus and Judaism, SCM Press, 1985, p. 72

16. Mark 14:57

17. Mark 13:2

18. Luke 23:27-31

19. Mark 13:1-2

20. John 2:19

21. Jeremiah $31: 31-4$

22. I Corinthians 15:3-8

23. Galatians 1:18-19

24. For a mathematical exposition of the points of this paragraph and their application to the Resurrection, see The Resurrection of God Incarnate, Appendix, 'Formalizing the Argument'. 